\title{
BUCKLING ASSESSMENT OF IMPERFECT CYLINDRICAL SHELLS UNDER AXIAL LOADS USING A GEP TECHNIQUE
}

Iman Mansouri

Scientific paper / Znanstveni rad

(Received: 16 November; accepted: 16 December)

Birjand University of Technology, Department of Civil Engineering, Birjand, Iran, Ph.D., Assistant Professor Corresponding author: mansouribiriandut.ac.ir

Alireza Farzampour

Department of Civil and Environmental Engineering, Virginia Tech, Blacksburg, United States, Ph.D.

Abstract: Determination of buckling behavior of shell structures has long been identified as a challenging task. This is largely because the buckling behavior is masked by local large deformations, which occur once the critical load is reached. This research proposes a novel technique to accurately predict the buckling load of imperfect cylindrical shells using gene expression programming (GEP), which is an evolutionary artificial intelligence method. An existing experimental data bank was employed for training and testing the program, and the obtained buckling load of shell structures were accordingly verified. From the results, it is concluded that GEP is a promising and reliable method to determine the buckling load of shell structures subjected to axial compression.

Keywords: Gene expression programming technique; shell structures; buckling load; axial compression

\section{PROCJENA IZVIJANJA NESAVRŠENE CILINDRIČNE LJUSKE PRI OSNOM OPTEREĆENJU PRIMJENOM GEP TEHNIKE}

Sažetak: Definiranje ponašanja pri izvijanju odavno je identificirano kao izazovan zadatak pri izučavanju plošnih konstrukcija. Razlog tomu je činjenica da lokalne velike deformacije nastaju nakon dosezanja kritičnog opterećenja pa je opće ponašanje pri izvijanju prikriveno tim deformacijama. Ovo istraživanje predlaže novi pristup za precizno određivanje sile pri izvijanju kod nesavršenih cilindričnih ljuski, primjenom programiranja genetičkim izrazom (GEP), evolucijske metode umjetne inteligencije. Za učenje i testiranje programa primijenjena je postojeća eksperimentalna baza podataka te je predložen izraz za silu pri izvijanju plošnih konstrukcija, koji je sukladno tome i verificiran. Zaključeno je da je GEP obećavajuća i pouzdana metoda za određivanje sile izvijanja kod osno naprezanih plošnih konstrukcija.

Ključne riječi: tehnika programiranja genetičkim izrazom; plošne konstrukcije; sila pri izvijanju; osno tlačno naprezanje

Mansouri, l., Farzampour, A. 


\section{INTRODUCTION}

Stiffened and unstiffened cylindrical shells are widely used in many applications such as in offshore structures, where their application is crucial. For these cylindrical shells subjected compressive loads, the buckling limit state needs to be considered because it has been reported that buckling is the primary limit state for cylindrical shells compared to plates and columns. Furthermore, the stability of shell structures is also governed by the buckling behavior [1, 2]. Hence, many researchers have studied this behavior to determine the most accurate capacity of cylindrical shells under compressive loads. On the other hand, the buckling analysis of such structures is considered a serious challenge, since the buckling load cannot be easily determined from the data analysis of experimental results [3,4]. Generally, shell structures exhibit significant initial geometric imperfections; hence, the determination of their buckling load has been reported to be approximate and imprecise [5]. Figure 1 illustrates the geometric features of a cylindrical shell structure with general geometric parameters.

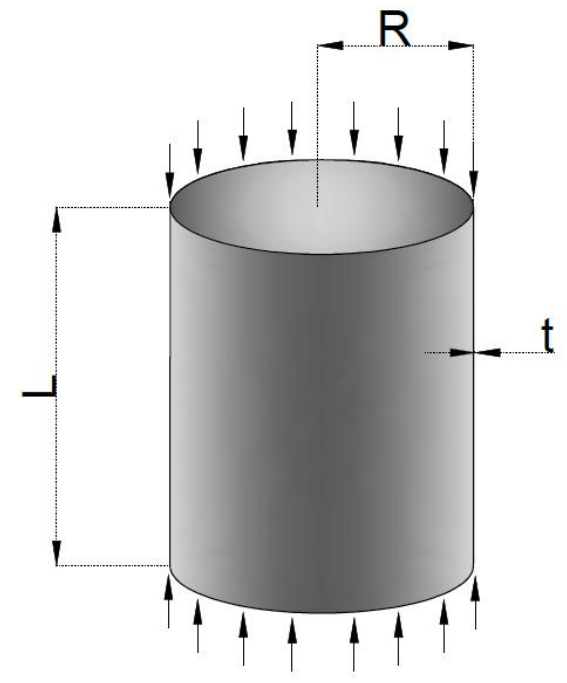

Figure 1 Geometric features of cylindrical shell structures

The stability of slender columns under compressive loads is assessed by the classical buckling theory of elastic structures proposed in Euler's investigations. The governing linear equations are solved by eigenvalue analysis to obtain the buckling loads and the corresponding failure modes as eigenvalues and eigenvectors, respectively [6]. However, experimental investigations and developments in metal constructions demonstrated that:

a) The classical buckling theory assessment generally overestimates the experimental buckling loads.

b) Wide ranges of buckling loads are obtained for similar specimens.

c) Catastrophic limit state failure occurred for significant number of specimens.

These findings prove the insufficiency of the classical buckling theory in specific applications, which necessitate further studies related to thin-shell structures.

There are many studies investigating the buckling behavior of shell structures to estimate the critical buckling load. Waszczyszyn and Bartczak investigated the critical buckling load of cylindrical shells with geometric imperfections using neural prediction and concluded that the application of imperfection parameters is an efficient method to analyze the experimental results of the buckling investigations [7]. They continued the research of Tadeusiewicz et al., who employed back-propagation neural networks (BPNNs) to determine the buckling load of cylindrical shells under axial compression [8]. Most recenty, Ghanbari Ghazijahani and Zirakian investigated the critical buckling load of thin shells by implementing extrapolation techniques [5]. The efficiency of Southwell, Massey, Modified, and Meck plotting methods in investigating the buckling behavior of shell structures were confirmed in their study.

Mansouri, l., Farzampour, A. 
Soft computing techniques have been employed to solve many structural engineering problems [9-12]. A novel soft computing technique, genetic programming (GP), was developed for engineering modeling [13-15]. In this method, program space is considered instead of data space, which facilitates the generation of prediction equations without prior assumptions. A number of studies implemented GP methodologies to identify complex relationships corresponding to the experimental data $[16,17]$. The gene expression programming (GEP), an extension of GP, has also been adopted in a number of studies, where programs of various sizes and shapes were developed in the form of linear chromosomes of fixed length. The GEP chromosomes consist of multiple genes, and each gene has a smaller subprogram. The GEP has been reported to be an efficient and applicable method compared to the previous traditional soft computing techniques (e.g., GP), which are used in limited number of studies on structural applications.

Unlike the regression techniques, which were being used previously, the GEP implements a trial-and-error method in a regular process of system identification; therefore, a structure can be modeled to fit appropriately with the training data [18]. In this research, the buckling load prediction was explored in detail using the GEP. A formula was derived by training the software using input data procured from the Delf University of Technology experimental data bank [19].

\section{GENE EXPRESSION PROGRAMMING}

\subsection{Brief outlook}

GEP, initially proposed by Ferreira, implements the principles of GA and genetic programming (GP) [20]. The GEP evaluation strategy of any scientific data is similar to the biological evaluation. GEP has five main components: (i) terminal set, (ii) functional set, (iii) fitness function, (iv) algorithm control parameters, and (v) termination criterion [21]. The search space is identified by the first three components, while the quality and speed of the search is governed by the last two components.

The GEP-based models and the corresponding equations, which are based on existing experimental data, differ from the conventional models, which were developed based on the general engineering principles such as the basic theories of elasticity and/or plasticity. Subsequently, modeling uncertainties resulting from simplifications and assumptions are significantly reduced [21].

As illustrated in Figure 2, in GEP algorithm, a random generation is developed from the initial generation. The chromosomes are accordingly converted into "an expression tree," and the fitness of each chromosome is computed. Further, the chromosomes are chosen based on their fitness, to be reproduced with proper modifications. The chromosomes of the new generation are subjected to similar developmental process, i.e., "expression of the genomes," "confrontation of the selection environment," and "reproduction with modification" [22]. This process is repeated until a satisfactory solution is obtained. 


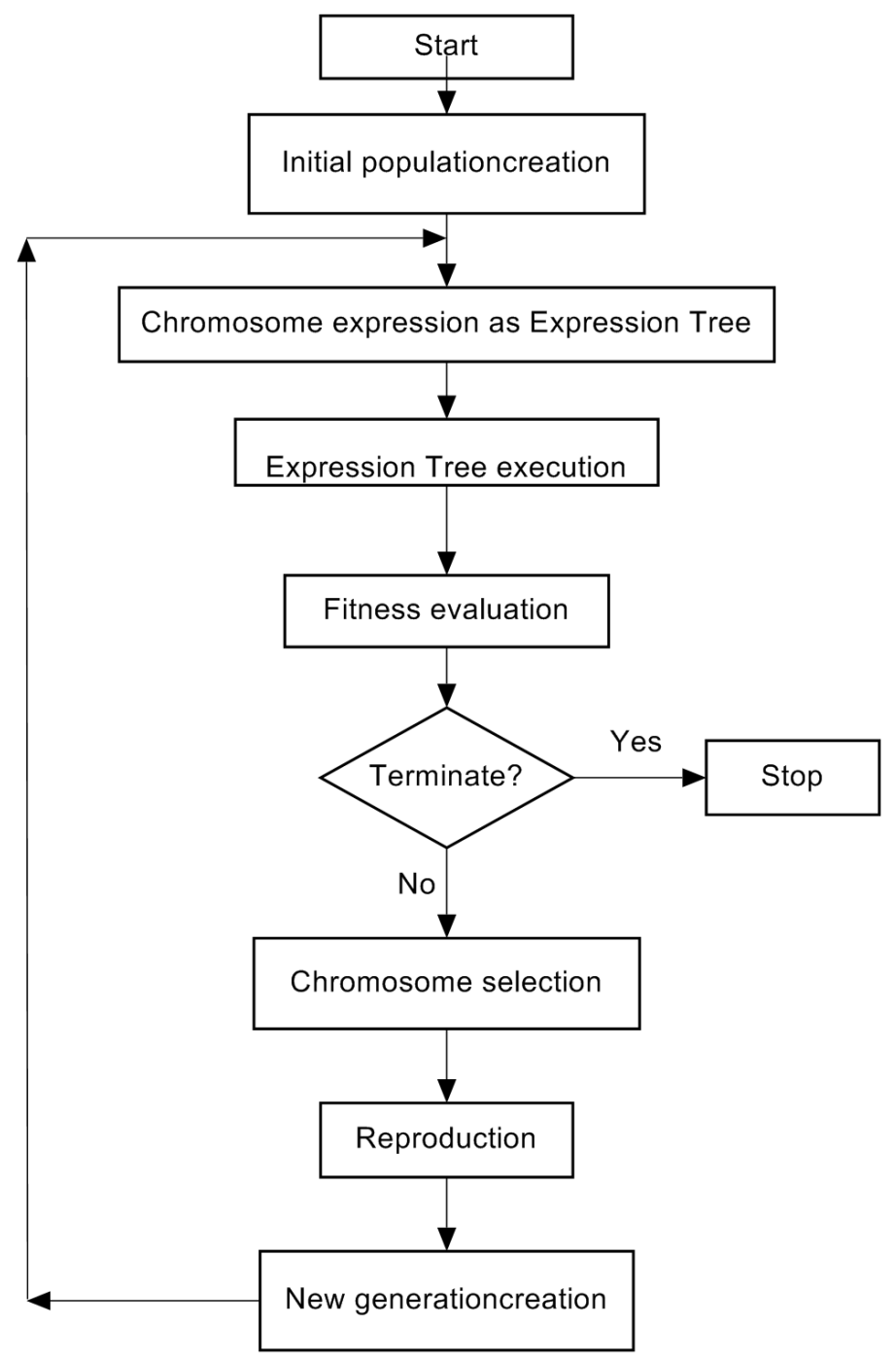

Figure 2 GEP flowchart [20]

\subsection{GEP features in this study}

In this study, a soft computation technique, the GEP, was performed to predict the axial buckling load of shell structures. The function set consisted of eight basic arithmetic operators $(+,-, x, \div, \sqrt{ }$, In, exp, power) and constants. The terminal set included four fundamental parameters of $P_{c r}$, as given in Eq. (1) [23].

$P_{c r}=f(E, R, t, L)$

where $P_{c r}$ corresponds to the critical buckling load of the shell specimen; $E$, the Young's modulus; $\mathrm{R}$, the radius; $t$, the thickness; and $L$, the length. It has been previously reported that the geometric parameters - including mostly the above parameters-significantly affect the buckling strength of shells [1, 24, 25]. Further, in this GEP model, the number of genes was considered as 2, mutation rate as 0.044 , inversion rate as 0.1 , one-point and two-point recombination rates as 0.3 , and gene recombination and transportation rates as 0.1 . During the training and testing of the GEP model, $R, t, L$ and $E$ were considered as input data (see Figure1); hence, $P_{c r}$ was obtained as an independent Mansouri, I., Farzampour, A. 
output in this study. Furthermore, this study was based on the recorded imperfections and shell specimen tests from the experimental data bank [19]. Table 1 summarizes the details of the specimens employed to train the soft computing model of GEP.

\section{ANALYSES AND DISCUSSIONS}

\subsection{GEP output for critical buckling load}

Among 35 experimental data from the data bank, 26 were randomly selected as the training set and the rest were used to test the proposed model's generalization capacity. The simplified analytic form of the proposed GEP model, expressed as Eq. (2), was eventually achieved; where $C_{0}=4.65$ and $C_{1}=9.84$ are constants.

$$
P_{c r}=E^{C_{0}^{2} \frac{t}{R}} L^{C_{1} \frac{t}{R}} R^{2}
$$

\subsection{Performance measures}

The accuracy and performance of the proposed formula were evaluated considering several statistical verification criteria such as the square correlation coefficient $\left(R^{2}\right)$, the root mean square error $(R M S E)$ and the mean absolute error $(M A E)$. This evaluation was conducted to simultaneously obtain high $R^{2}$ and low RMSE and MAE values, which signify the most precise approximation. These criteria can be calculated based on equations (3)-(5):

$$
\begin{aligned}
& R^{2}=1-\frac{\sum_{i=1}^{n}\left(p_{i}-o_{i}\right)^{2}}{\sum_{i=1}^{n}\left(o_{i}-\bar{o}_{i}\right)^{2}} \\
& R M S E=\sqrt{\frac{\sum_{i=1}^{n}\left(p_{i}-o_{i}\right)^{2}}{n}} \\
& M A E=\frac{\sum_{i=1}^{n}\left|p_{i}-o_{i}\right|}{n}
\end{aligned}
$$

where $p_{i}$ indicates the predicted values of the buckling load, $n$ is the number of data and $o_{i}$ and $\overline{o_{i}}$ denote the observed and average observed experimental output values of the buckling load, respectively. It was observed that the performance of the metaheuristic algorithms could not be assessed from the results of a single run due to the random nature of the computations. Hence, training and testing were intermittently conducted to reduce any possible errors.

Comparison of the predicted values with the measured values is presented in Figure 3. The efficiency and precision in the learning of the proposed model was demonstrated by the training set results. The comparison of the values obtained from the GEP method with the corresponding experimental results demonstrates the high generalization capacity of the proposed models and the low error values obtained by implementing the proposed equations. Hence, it can be concluded that this method can derive a nonlinear relationship between the input and the output parameters, 
with high correlation and comparatively low errors. Table 2 presents the results of statistical analysis of the results obtained from training and testing sets in detail.

\section{Training set}

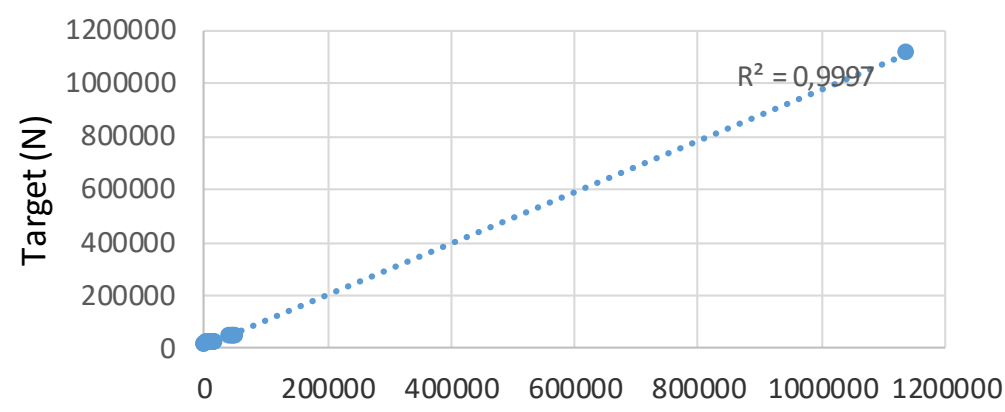

Model (N)

(a)

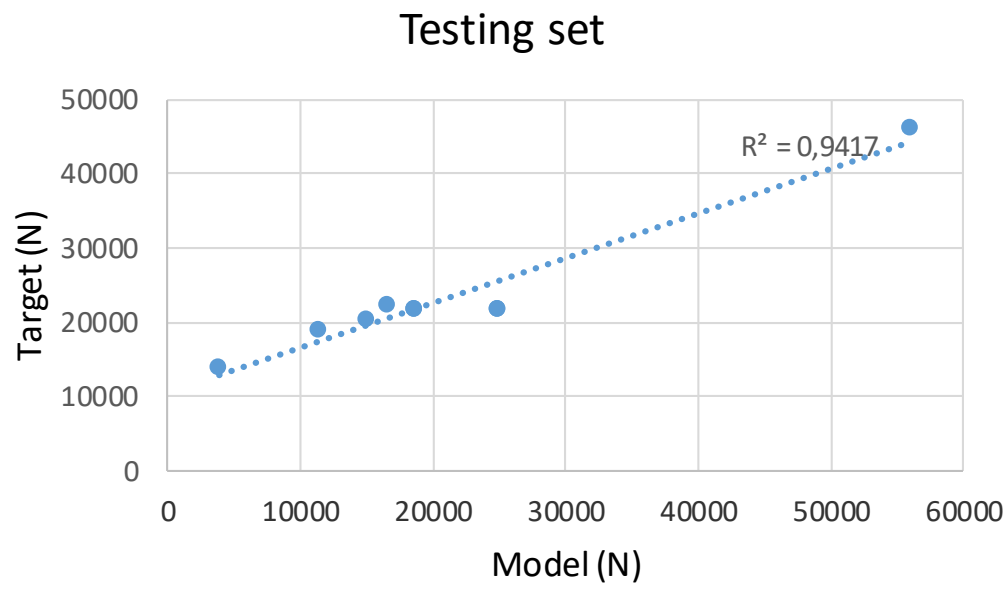

(b)

Figure 3 Correlation of the measured and predicted values in: (a) training and (b) testing stages

The values of $R^{2}$, RMSE, and MAE calculated with the results of the training and testing sets indicate that GEP can be reliably utilized to predict the buckling load of shell structures under axial compressive load during both training and testing stages. The curve fitting, target sorted fitting, and standard distributions of both training and testing stages are depicted in Figures 4-6, respectively. The results demonstrate that the proposed model can follow the targeted curve values with satisfactory accuracy. 
Buckling assessment of imperfect cylindrical shells under axial loads using a GEP technique

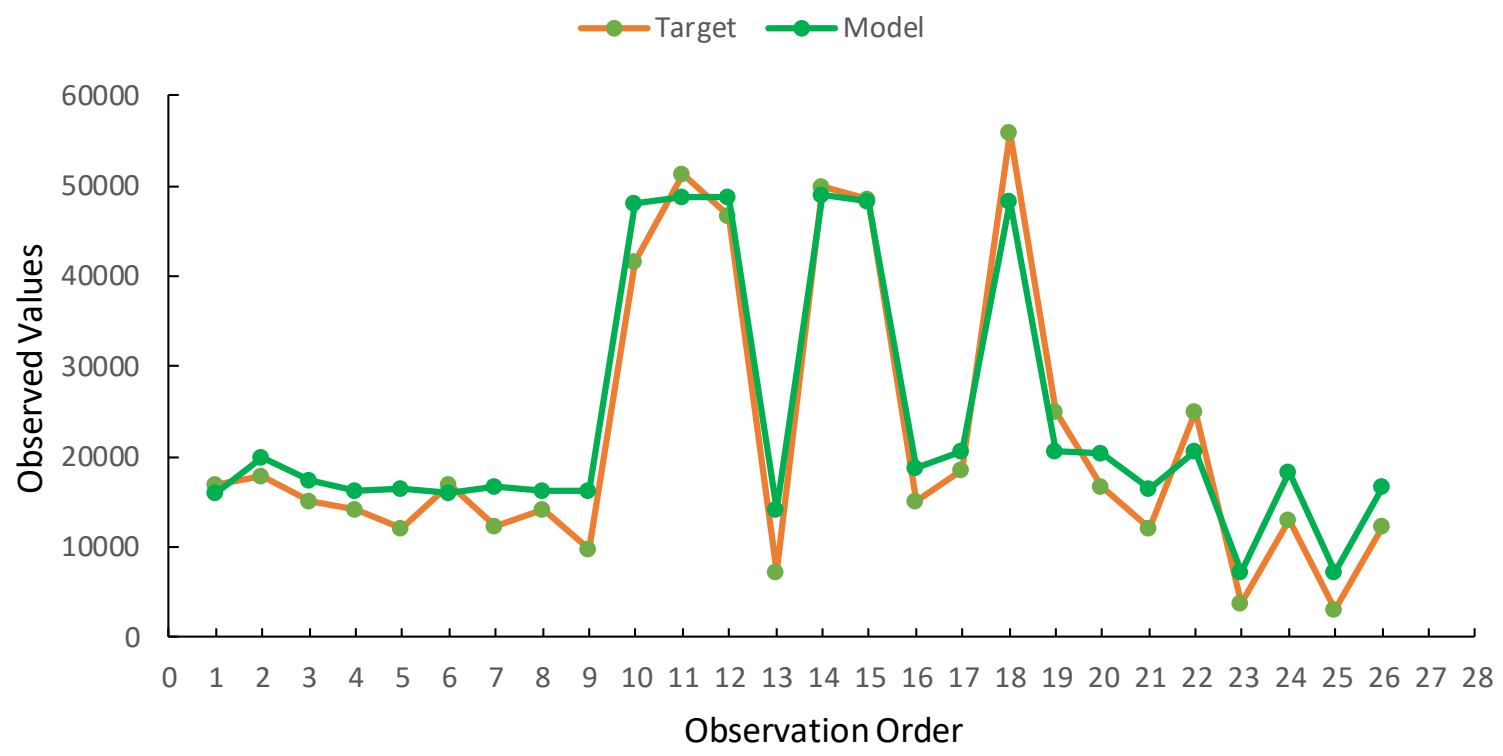

(a)

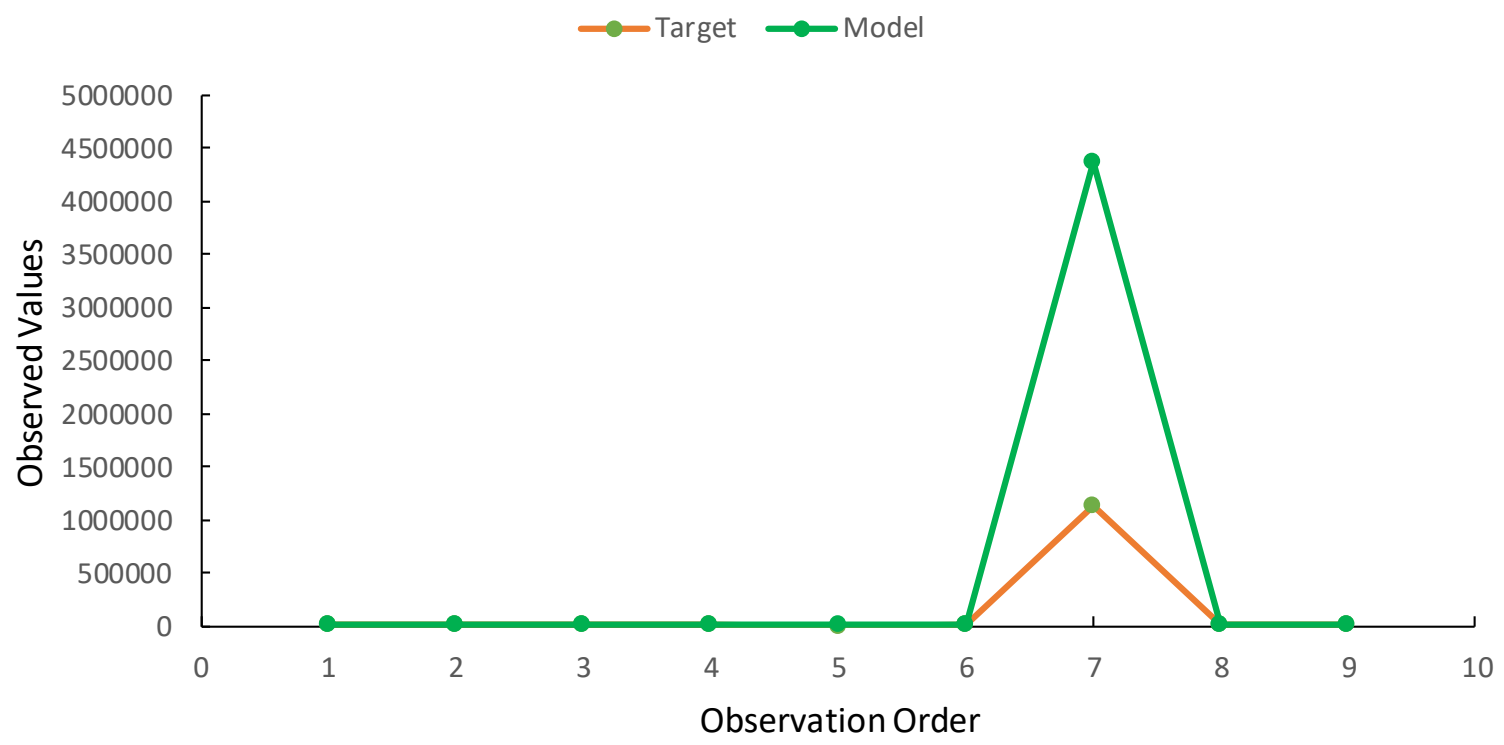

(b)

Figure 4 The curve fitting for (a) training and (b) testing stages 
Buckling assessment of imperfect cylindrical shells under axial loads using a GEP technique

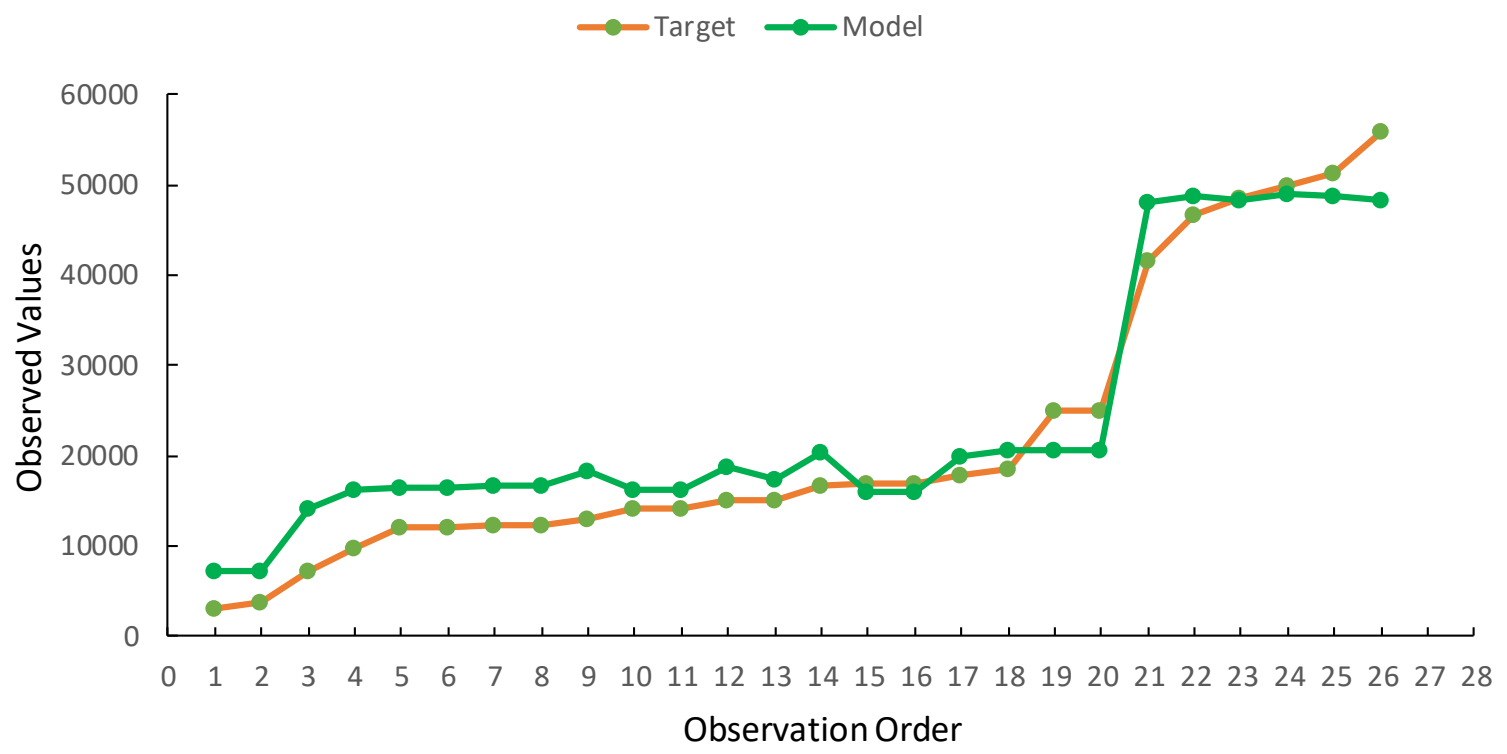

(a)

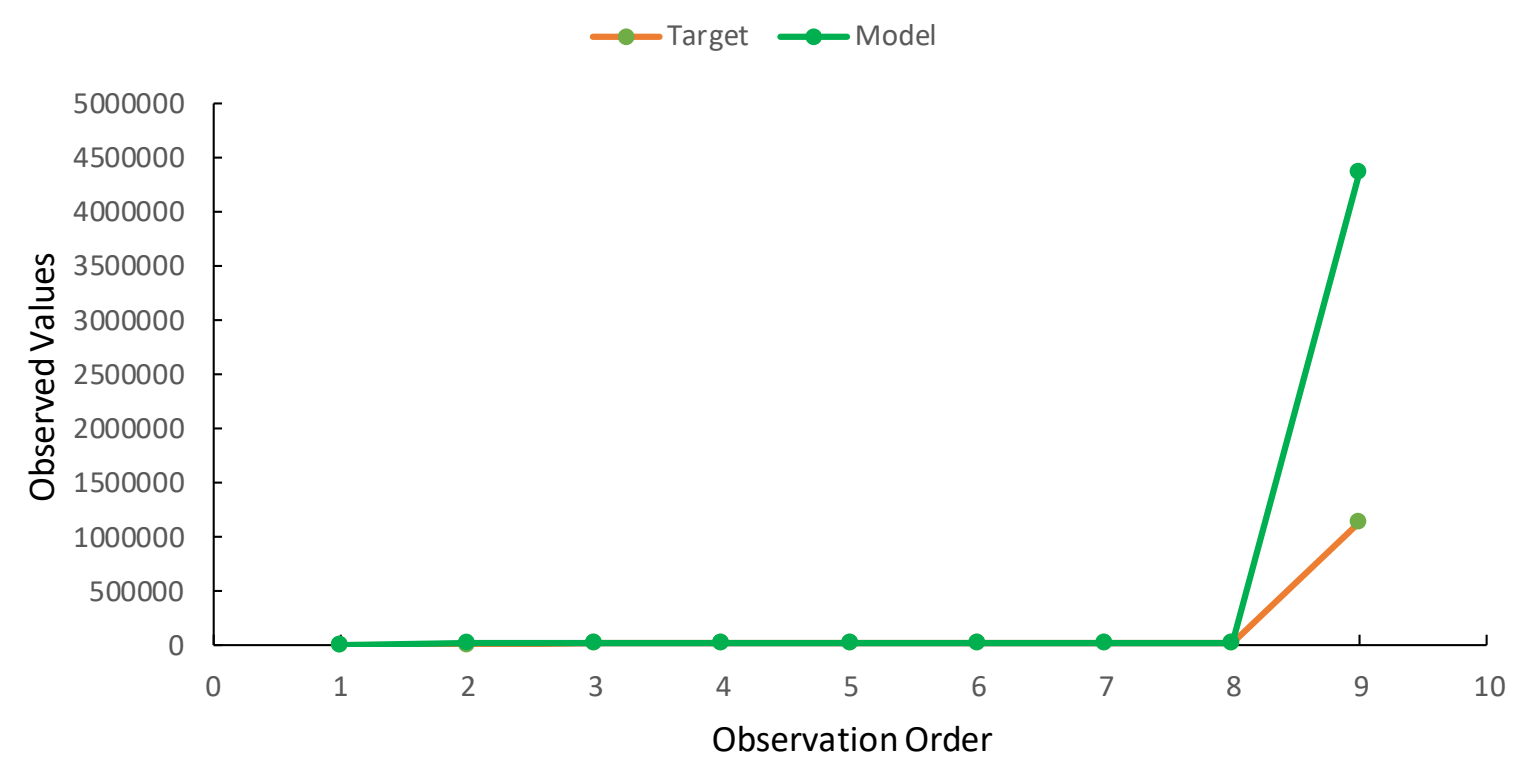

(b)

Figure 5 Target sorted fitting for (a) training and (b) testing stages 
Buckling assessment of imperfect cylindrical shells under axial loads using a GEP technique

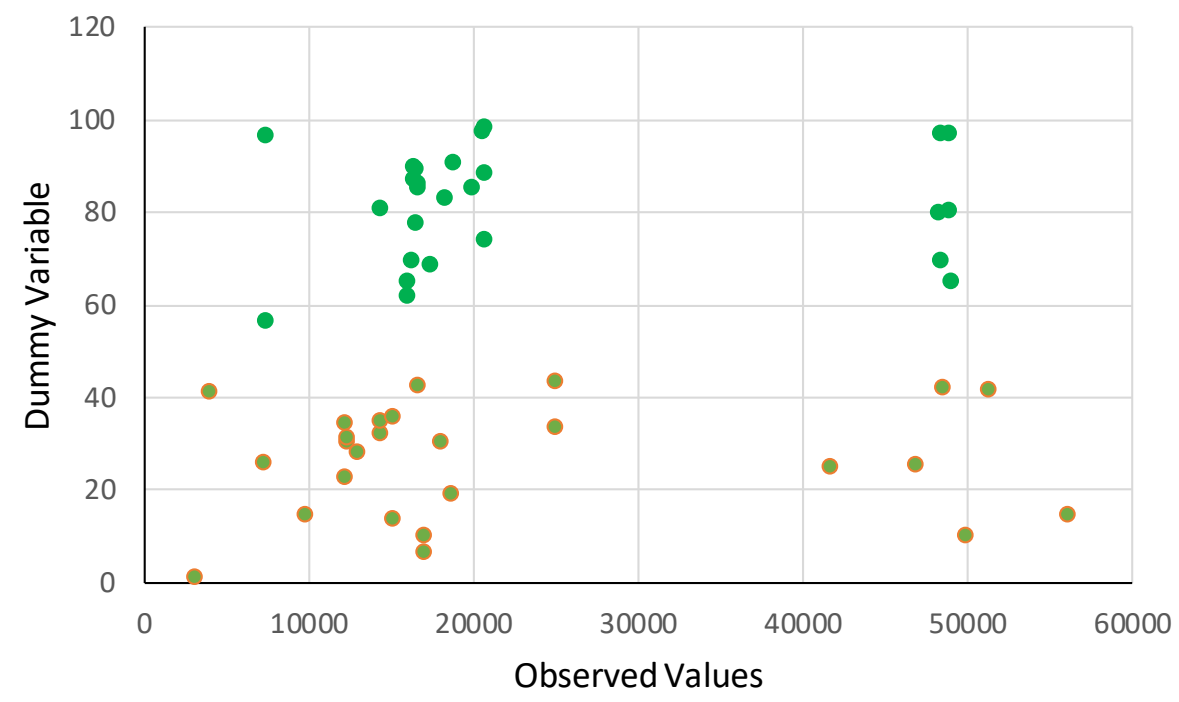

(a)

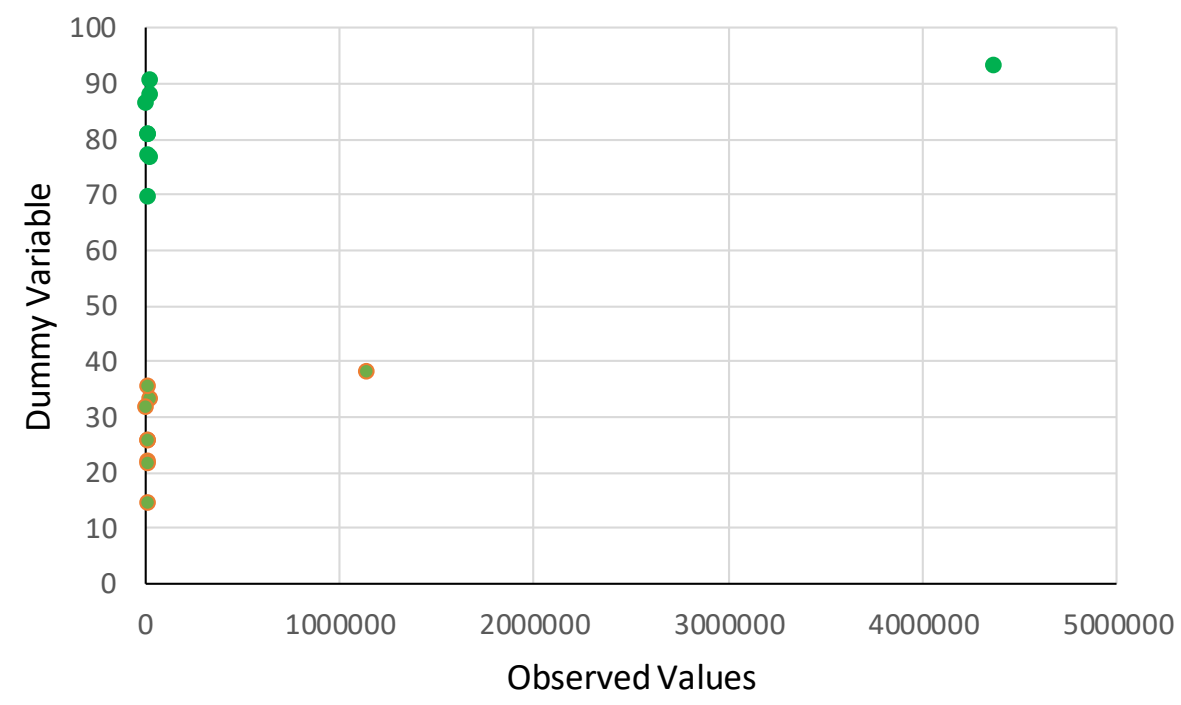

(b)

Figure 6 The standard distributions for (a) training and (b) testing stages

Table 2. Statistical values of $P_{c r}$ from the GEP model

\begin{tabular}{ccc}
\hline Statistical parameters & Training set & Testing set \\
\hline$R^{2}$ & 0.9997 & 0.9417 \\
$R M S E$ & 8130.49 & 6305.57 \\
$M A E$ & 6442.09 & 5704 \\
\hline
\end{tabular}




\section{CONCLUSIONS}

The difficulties in creating buckling load prediction models using classical GP and GEP techniques were identified. It has been reported that the performance of these models cannot be enhanced by using a number of expressions and complicated functions or by changing the runtime and the depth of genes. However, such measures might result in over-trained models after some generations. This study proposes a hybrid model of GEP-GA, which implements the principles of GA into GEP technique to improve the performance by creating gene weights for obtaining GEP expressions.

The efficiency of GEP technique in estimating the buckling load of imperfect cylindrical shells under axial compressive load was investigated. The experimental results obtained from previous literature and the proposed empirical model were utilized to study the buckling behavior of shell structures under axial loads. The study was conducted on two sets of data (training and testing data), which were based on the recorded geometric imperfections and the buckling load from experimental results.

The results obtained from the model showed an excellent agreement with the experimental data, and the statistical parameters R2, MAE, and RMSE indicated a good precision. Hence, it is concluded that GEP can be reliably utilized to predict the buckling load of shell structures subjected to axial compressive loads in both training and testing stages.

\section{Appendix}

Table 1 Experimental database obtained from the data bank [19]

\begin{tabular}{cccccc}
\hline No. & $\boldsymbol{R}(\mathrm{mm})$ & $\boldsymbol{t}(\mathbf{m m})$ & $\boldsymbol{L}(\mathrm{mm})$ & $\boldsymbol{E}(\mathrm{MPa})$ & $\boldsymbol{P}_{\boldsymbol{c r}}(\mathrm{N})$ \\
\hline 1 & 101.6 & 0.0986 & 196.85 & 172400 & 2676.5 \\
2 & 101.6 & 0.0975 & 196.85 & 172400 & 3048.8 \\
3 & 101.6 & 0.0978 & 196.85 & 172400 & 3905.5 \\
4 & 101.6 & 0.205 & 196.85 & 106500 & 11326 \\
5 & 101.6 & 0.1852 & 144.78 & 106500 & 7178.5 \\
6 & 101.6 & 0.2634 & 140.97 & 106500 & 16661.2 \\
7 & 117.86 & 0.4564 & 148.59 & 180600 & 56050 \\
8 & 118.36 & 0.4526 & 148.59 & 180600 & 48500 \\
9 & 117.91 & 0.46 & 148.59 & 180600 & 46800 \\
10 & 118.49 & 0.4554 & 148.59 & 180600 & 51350 \\
11 & 118.49 & 0.4567 & 148.59 & 180600 & 49900 \\
12 & 117.86 & 0.4544 & 148.59 & 180600 & 41700 \\
13 & 101.6 & 0.236 & 133.35 & 68950 & 12986.5 \\
14 & 101.6 & 0.2413 & 133.35 & 68950 & 15060.3 \\
15 & 101.6 & 0.2553 & 133.35 & 68950 & 17967.2 \\
16 & 101.6 & 0.2649 & 133.35 & 68950 & 18575.7 \\
17 & 101.6 & 0.2131 & 133.35 & 68950 & 12224.1 \\
18 & 101.6 & 0.2149 & 133.35 & 68950 & 12277.5 \\
19 & 101.6 & 0.2098 & 146.3 & 68950 & 9742.9 \\
20 & 101.6 & 0.2116 & 139.7 & 68950 & 14286.3 \\
21 & 101.6 & 0.2238 & 139.7 & 68950 & 15107.4 \\
22 & 101.6 & 0.2065 & 137.16 & 68950 & 16997.9 \\
\hline
\end{tabular}

Mansouri, l., Farzampour, A. 
Buckling assessment of imperfect cylindrical shells under axial loads using a GEP technique

\begin{tabular}{lccccc}
23 & 101.6 & 0.2649 & 141.73 & 68950 & 24950.4 \\
24 & 101.6 & 0.236 & 133.35 & 68950 & 12986.5 \\
25 & 101.6 & 0.2413 & 133.35 & 68950 & 15060.3 \\
26 & 101.6 & 0.2553 & 133.35 & 68950 & 17967.2 \\
27 & 101.6 & 0.2649 & 133.35 & 68950 & 18575.7 \\
28 & 101.6 & 0.2131 & 133.35 & 68950 & 12224.1 \\
29 & 101.6 & 0.2149 & 133.35 & 68950 & 12277.5 \\
30 & 101.6 & 0.2098 & 146.3 & 68950 & 9742.9 \\
31 & 101.6 & 0.2116 & 139.7 & 68950 & 14286.3 \\
32 & 101.6 & 0.2238 & 139.7 & 68950 & 15107.4 \\
33 & 101.6 & 0.2065 & 137.16 & 68950 & 16997.9 \\
34 & 101.6 & 0.2649 & 141.73 & 68950 & 24950.4 \\
35 & 946.2 & 0.6426 & 2743.2 & 68950 & 1138325 \\
\hline
\end{tabular}

\section{References}

[1] Farzampour, A.; Laman, J.A.; Mofid, M. 2015: Behavior prediction of corrugated steel plate shear walls with openings, Journal of Constructional Steel Research, 114, pp. 258-268, https://doi.org/10.1016/j.jcsr.2015.07.018

[2] Teng, J.G.; Rotter, J.M. 2006: Buckling of thin metal shells, CRC Press.

[3] Farzampour, A.; Mansosuri, l.; Hu, J.W. 2018: Seismic behavior investigation of the corrugated steel shear walls considering variations of corrugation geometrical characteristics, International Journal of Steel Structures, 18, pp. 1297-1305, https://doi.org/10.1007/s13296-018-0121-z

[4] Singer, J.; Arbocz, J.; Weller, T. 2002: Buckling Experiments, Experimental Methods in Buckling of Thin-Walled Structures, John Wiley \& Sons.

[5] Ghanbari Ghazijahani, T.; Zirakian, T. 2014: Determination of buckling loads of conical shells using extrapolation techniques, Thin-Walled Structures, 74, pp. 292-299, https://doi.org/10.1016/j.tws.2013.09.003

[6] Zhu, E.; Mandal, P.; Calladine, C.R. 2002: Buckling of thin cylindrical shells: an attempt to resolve a paradox, International Journal of Mechanical Sciences, 44, pp. 1583-1601, https://doi.org/10.1016/S0020-7403(02)00065$\underline{6}$

[7] Waszczyszyn, Z.; Bartczak, M. 2002: Neural prediction of buckling loads of cylindrical shells with geometrical imperfections, International Journal of Non-Linear Mechanics, 37(4-5), pp. 763-775, https://doi.org/10.1016/S0020-7462(01)00111-1

[8] Waszczysznk, Z. 1999. Neural Networks in the Analysis and Design of Structures, Springer.

[9] Khorami, M.; Khorami, M.; Alvansazyazdi, M.; Shariati, M.; Zandi, Y.; Jalali, A.; Tahir, M.M. 2017: Seismic performance evaluation of buckling restrained braced frames (BRBF) using incremental nonlinear dynamic analysis method (IDA), Earthquake and Structures, 13(6), pp. 531-538,

[10] Heydari, A.; Shariati, M. 2018: Buckling analysis of tapered BDFGM nano-beam under variable axial compression resting on elastic medium, Structural Engineering and Mechanics, 66(6), pp. 737-748,

[11] Mansouri, I.; Shariati, M.; Safa, M.; Ibrahim, Z.; Tahir, M.M.; Petković, D. 2017: Analysis of influential factors for predicting the shear strength of a V-shaped angle shear connector in composite beams using an adaptive neurofuzzy technique, Journal of Intelligent Manufacturing, pp. 1-11, https://doi.org/10.1007/s10845-017-1306-6

[12] Toghroli, A.; et al. 2018: Evaluation of the parameters affecting the Schmidt rebound hammer reading using ANFIS method, Computers and Concrete, 21(5), pp. 525-530, https://doi.org/10.12989/cac.2018.21.5.525

Mansouri, I., Farzampour, A. 
[13] Gandomi, A.H.; Alavi, A.H.; Kazemi, S.; Gandomi, M. 2014: Formulation of shear strength of slender RC beams using gene expression programming, part l: Without shear reinforcement, Automation in Construction, 42, pp. 112-121, https://doi.org/10.1016/j.autcon.2014.02.007

[14] Ebrahimzade, H.; Khayati, G.R.; Schaffie, M. 2018: A novel predictive model for estimation of cobalt leaching from waste Li-ion batteries: Application of genetic programming for design, Journal of Environmental Chemical Engineering, 6(4), pp. 3999-4007, https://doi.org/10.1016/j.jece.2018.05.045

[15] Mahdavi Jafari, M.; Khayati, G.R. 2018: Prediction of hydroxyapatite crystallite size prepared by sol-gel route: gene expression programming approach, Journal of Sol-Gel Science and Technology, 86(1), pp. 112-125, https://doi.org/10.1007/s10971-018-4601-6

[16] Gandomi, A.H.; Alavi, A.H. 2012: A new multi-gene genetic programming approach to nonlinear system modeling. Part I: Materials and structural engineering problems, Neural Computing and Applications, 21(1), pp. 171-187, https://doi.org/10.1007/s00521-011-0734-z

[17] Sonebi, M.; Cevik, A. 2009: Genetic programming based formulation for fresh and hardened properties of selfcompacting concrete containing pulverised fuel ash, Construction and Building Materials, 23(7), pp. 2614-2622, https://doi.org/10.1016/j. conbuildmat.2009.02.012

[18] Chen, L. 2003: Study of applying macroevolutionary genetic programming to concrete strength estimation, Journal of Computing in Civil Engineering, 17(4), pp. 290-294, https://doi. org/10.1061/(ASCE)0887-3801(2003)17:4(290)

[19] Arbocz, J.; Abramovich, H. 1979: The initial imperfection data bank at the Delf University of Technology: Part I, Delf University of Technology.

[20] Ferreira, C. 2001: Gene expression programming: a new adaptive algorithm for solving problems

[21] Koza, J.R. 1992: Genetic programming: on the programming of computers by means of natural selection vol. 1.

[22] Güllü, H. 2012: Prediction of peak ground acceleration by genetic expression programming and regression: A comparison using likelihood-based measure, Engineering Geology, 141-142, pp. 92-113, https://doi.org/10.1016/j.enggeo.2012.05.010

[23] Wang, C.Y.; Shih, H.P.; Hong, J.H.; Raikar, R.V. 2013: Prediction of bridge pier scour using genetic programming, Journal of Marine Science and Technology (Taiwan), 21(4), pp. 483-492, https://doi.org/ 10.6119/JMST-0130523-1

[24] Farzampour, A.; Eatherton, M.R. 2018: Parametric study on butterfly-shaped shear links with various geometries. Proceedings of 11th National Conference on Earthquake Engineering, 11NCEE, Los Angeles, USA

[25] Farzampour, A.; Mansosuri, I.; Hu, J.W. 2017: Investigation of seismic behavior of corrugated steel shear walls considering variations of corrugation geometrical characteristics. Proceedings of 9th International Symposium on Steel Structures. Jeju, Korea 